\title{
Availability of MADLDI-TOF MS for Identification of Gram Positive Bacilli Isolated from Blood Culture
}

\author{
Jin-Un Choi ${ }^{1,}$, Sang-Ha Kim ${ }^{2,8}$, Su-Jeong Hwang ${ }^{3}$, Young-Bin Yu ${ }^{5}$, \\ Sunghyun $\mathrm{Kim}^{4, \dagger}$ and Young-Kwon Kim ${ }^{5, \dagger}$ \\ ${ }^{1}$ Department of Laboratory Medicine, Chonnam National University Hospital, Gwangju 61469, Korea \\ ${ }^{2}$ Department of Laboratory Medicine, Konyang University Hospital, Daejeon 35365, Korea \\ ${ }^{3}$ Department of Dental Hygiene, College of Medical Sciences, Konyang University, Daejeon 35365, Korea \\ ${ }^{4}$ Department of Clinical Laboratory Science, College of Health Sciences, \\ Catholic University of Pusan, Busan 46252, Korea \\ ${ }^{5}$ Department of Biomedical Laboratory Science, College of Medical Sciences, \\ Konyang University, Daejeon 35365, Korea
}

In the present study, results of the identification of Gram-positive bacilli (GPB) were analyzed by using the MALDITOF MS technique to score each 2-year blood culture at a university hospital. In addition, 16S rRNA sequence analyses and MALDI-TOF MS results are compared to targeting strains that had been isolated two or more times within the same patient, to evaluate the usefulness of MALDI-TOF MS in GPB identification. According to the cut-off ( $\geq 1.7)$ criteria, there were 410 (57.5\%) reliable strains and 303 (42.5\%) non-identified strains among the GPB identification results of 713 strains, using a microflex MALDI Biotyper (Bruker Daltonik GmbH, Bremen, Germany). The isolation appeared most often in the following order: Corynebacterium striatum, Bacillus cereus, Bacillus subtilis, Paenibacillus urinalis, and Listeria monocytogenes. Nearly three-fourths, 66 out of $89(74.2 \%)$ of the strains for Corynebacterium striatum; 44 out of $60(73.3 \%)$ strains for Bacillus cereus; and all (25 out of 25, 100\%) Listeria monocytogenes strains were identified by their high scores of 2.0 or higher. Most (293 strains out of 303) non-identified strains were strains isolated only once and not significant as infectious bacilli. A total of 43 out of $50(86.0 \%)$ strains matched and were able to be identified based on the 16 rRNA sequencing comparison results of strains that were isolated twice or more within the same patient and significant as infection bacilli. Non-matching among 5 out of 7 strains was not identified, even with MALDI-TOF MS. In conclusion, GPB can be identified in blood cultures using MALDI-TOF MS. This can be done accurately with ease, rapidly, and at a low cost. It is also thought to be helpful in GPB diagnosis and treatment.

Key Words: Blood culture, Gram positive bacilli, MADLDI-TOF MS, 16S rRNA sequencing

\footnotetext{
* Received: March 5, 2018 / Revised: April 25, 2018 / Accepted: May 17, 2018

$\S$ Jin-Un Choi and Sang-Ha Kim contributed equally to this article.

${ }^{\dagger}$ Corresponding author: Sunghyun Kim. Department of Clinical Laboratory Science, College of Health Sciences, Catholic University of Pusan, Busan 46252 , Korea.

Tel: +82-51-510-0560, Fax:+82-51-510-0568, e-mail: shkim0423@cup.ac.kr

${ }^{\dagger}$ Corresponding author: Young-Kwon Kim. Department of Biomedical Laboratory Science, College of Medical Sciences, Konyang University, Daejeon 35365 , Korea.

Tel: +82-42-660-6371, Fax:+82-42-543-6370, e-mail: ykkim3245@konyang.ac.kr

(C) The Korean Society for Biomedical Laboratory Sciences. All rights reserved.

(c) This is an Open Access article distributed under the terms of the Creative Commons Attribution Non-Commercial License (http://creativecommons.org/licenses/by-nc/3.0/) which permits unrestricted non-commercial use, distribution, and reproduction in any medium, provided the original work is properly cited.
} 


\section{서 론}

최근 의료기관의 임상미생물검사실에서는 Matrix-assisted laser desorption ionization-time of flight mass spectrometry (MALDI-TOF MS)를 기반으로 한 원인균 동정 시스템의 도입이 증가하고 있는 상황이다. 이 검사법은 임상검체로 부터 분리 배양된 단일 집락을 이온화하여 진공관에서 검 출기에 도달하는 시간을 근거로 구성 물질의 질량을 측정 하는 방법으로 동정 시간은 균주 당 평균 약 6 분 정도 소 요된다(Holland et al., 1996). 동정을 위한 비용은 상품화된 진단 키트를 포함해 전통적 동정 방법(Seng et al., 2009)의 약 20 30\% 정도로 미생물 검사실에서 이용하기에 간편하 고, 동정에 소요되는 시간 또한 매우 짧아 매우 경제적인 방법으로 알려져 있다(Bizzini et al., 2010; Stevenson et al., 2010).

그람 양성 막대균(Gram positive bacilli, GPB)의 대부분 은 주로 환경에서 존재하며 비병원성으로 알려져 있었기 때문에, 그 동안 임상미생물검사실에서는 이를 오염균으 로 간주하여 정확한 동정을 시행하지 않는 것이 일반적이 었다(Funke et al., 1997). 하지만, GPB 중 몇몇 병원성 세균 종은 동정을 하는 것은 임상적으로 중요하다. 특히, 최근 면역 저하자나 체내 삽입기구를 처치하는 환자가 증가하 고 있으며, 항생제 사용 또한 증가함에 따라 $\mathrm{GPB}$ 에 의한 기회감염이 증가하고 있는 추세이며, $\mathrm{GPB}$ 의 정확한 동정 필요성이 대두되고 있으며, 이를 통해 감염의 정확한 원 인 분석이 가능하고, 적절한 치료를 위해 큰 도움을 줄 수 있을 것으로 여겨진다(Adderso et al., 2008).

일반적으로 혈액 배양(Blood culture)으로부터 분리되는 $\mathrm{GPB}$ 는 비용의 효용적인 측면에서 동일 환자에서 2회 이 상 분리될 경우에만 제한적으로 원인균 동정을 시행하 지만, 기존에 임상미생물검사실에서 시행하고 있는 원인 균 동정 방법은 많은 시간이 소요되고, 항상 동일한 결과 를 나타내지 않는다(Barberi et al., 2004). 따라서, 16S rRNA 염기서열 분석을 이용한 분자유전학적 검사 방법을 이 용하여 확인 동정을 시행하고, 이를 표준법(gold standard method)으로 도입하고 있지만, 이 검사법은 비용과 시간이 많이 소요된다는 제한점이 있다.

MALDI-TOF MS 기반 원인균 동정 시스템을 이용한 기 존의 많은 연구들은 대부분 임상미생물검사실에서 주로 분리되는 그람 양성 알균(Gram positive cocci, GPC), 그람 음성 막대균(Gram negative bacilli, GNB)을 표적으로 하고
있으며, 일부는 GPB를 대상으로 진행되었다(Carbonnelle et al., 2012; Dubois et al., 2012). 따라서, 본 연구에서는 국내 의 한 대학병원의 혈액 배양으로부터 분리 배양된 $\mathrm{GPB}$ 를 대상으로 MALDI-TOF MS를 실시하여 혈액 배양에서 분 리된 $\mathrm{GPB}$ 의 동정 균주 수와 미동정 균주 수를 비교해 보 았고, 동일 환자에서 2회 이상 분리된 균주를 대상으로 $16 \mathrm{~S}$ rRNA 염기서열 분석을 함께 실시하여 그 결과를 비 교함으로써, $\mathrm{GPB}$ 를 동정함에 있어서 MALDI-TOF MS를 기반으로 한 원인균 동정 시스템의 유용성을 평가해보고 자 하였다.

\section{재료 및 방법}

\section{임상검체}

2014년 10월부터 2016년 9월까지 국내의 한 대학병원에 서 혈액 배양이 의뢰된 임상검체로부터 분리 배양된 GPB 총 713주를 대상으로 연구를 실시하였다.

\section{혈액 배양}

혈액 배양은 산소성 배지(BacT/ALERT FA Plus, FA와 BACTEC TM Plus Aerobic/F), 무산소성 배지(BacT/ALERT Standard Anaerobic, SN와 BACTEC TM Plus Anerobic/F)에 접종하고 각각 $\mathrm{BacT} / \mathrm{ALERT}$ 3D Blood Culture System (bioMérieuxInc., Durham, NC, USA)과 BD BACTEC ${ }^{\mathrm{TM}} \mathrm{FX}$ blood culture system (BD, Spark, MD)에 5일간 배양하였다. 양성이 나온 혈액 배양 병을 5\% Sheep Blood Agar Plate (HANIL KOMED)에 접종하여 $5 \% \mathrm{CO}_{2}, 35^{\circ} \mathrm{C}$ 배양기에서 24시간 또는 48시간 배양하였다.

\section{MALDI-TOF MS System을 이용한 그람 양성 막대균 (GPB)의 동정}

GPB로 확인된 균주를 대상으로 Microflex MALDI Biotyper (Bruker Daltonik GmbH, Bremen, Germany) 장비로 검 사를 수행한 후, MALDI Biotyper RTC software (V. 3.1)를 이 용해 결과를 분석하여 세균 종을 동정하였다. 직접 도말법 은 하룻밤 배양한 신선한 집락을 멸균 Wooden applicator 를 이용해 MSP 96 target polished steel BC microscout Target plate (Bruker Daltonics)에 도말하고, 세균이 마른 후 매트 릭스 용액 $(50 \%$ acetonitrile, $2.5 \%$ trifluoroacetic acid $)$ 에 포화 된( $\alpha$-cyano-4-hydroxycinnamic acid)을 더한 시약 $1 \mu \mathrm{L}$ 를 가하고, 실온에서 완전히 건조시킨 후 microflex MALDI Biotyper 장비에 장착하였다. Bacterial test standard (BTS)를 
사용하여 장비 Calibration을 실시하였고, $\mathrm{m} / \mathrm{z}$ 2,000 20,000 범위에서 측정된 Mass spectra 동정 결과는 MALDI Biotyper RTC software (V. 3.1)를 이용해 분석하였다. 장비 회사 에서 제시하는 표준 기준을 기반으로 하여 Cut-off score가 2.0 이상이면 균 종 동정, 1.7 이상이면서 2.0 미만인 경우 균 속 동정이 가능한 것으로 판단하였고, 1.7 미만인 경우 신뢰성이 없는 것으로 간주하였다.

\section{$16 \mathrm{~S}$ rDNA 염기서열 분석}

Genomic DNA 추출: 혈액 배양으로부터 분리 배양된 $\mathrm{GPB}$ 의 gDNA 추출은 Phosphate buffered saline (PBS) $1 \mathrm{~mL}$ 에 집락 $3 \sim 4$ 개를 혼탁시킨 후 $8,000 \times \mathrm{G}$ 에서 5 분간 원심 분리 하였다. 침사층을 제외한 상층액을 제거한 후 Lysis solution (DW 1 L, Tris base $1.212 \mathrm{~g}$, EDTA $0.372 \mathrm{~g}$, Triton $1 \mathrm{~mL}$ $/ 1 \mathrm{~L}) 200 \mu \mathrm{L}$ 를 첨가하고 균을 혼탁한 후 $8,000 \times$ G에서 5 분간 원심분리 하였다. Lysis 과정을 3 회 반복 후, 멸균 $\mathrm{DW} 200 \mu \mathrm{L}$ 에 침사층을 혼탁시킨 후 $100^{\circ} \mathrm{C}$ 에서 30 분 동안 가열하여 $\mathrm{gDNA}$ 가 유리되도록 하였다. 이후 $13,000 \mathrm{x} \mathrm{G}$, $4{ }^{\circ} \mathrm{C}$ 에서 10 분간 원심분리 하여 상층액을 취한 후 사용 전 까지 $-20^{\circ} \mathrm{C}$ 에서 냉동보관 하였고, 염기서열 분석을 위한 $\mathrm{PCR}$ 수행 시 $\mathrm{gDNA}$ 의 농도를 $100 \mathrm{ng}$ 에 맞추어 사용하 였다.

\section{$16 \mathrm{~S}$ rDNA 염기서열 분석을 위한 PCR 및 염기서열 분} 석: $16 \mathrm{~S} \mathrm{rDNA}$ 염기서열 분석을 위한 $\mathrm{PCR}$ 을 수행하기 위 해 Forward primer인 16S-rRNA1 (5'-AGT TTG ATC CTG GCT CAG-3')와 Reverse primer인 16S-rRNA2 (5'-GGT TAC CTT GTT ACG ACT T-3')를 이용하였다. Primer 각각 20 pmol $1 \mu \mathrm{L}$, dNTPs $1 \mu \mathrm{L}, 10 \mathrm{x}$ Reaction buffer $(1 \mathrm{x}$ : $10 \mathrm{mM}$ Tris-HCL, $1.5 \mathrm{mM} \mathrm{KCL}, 0.1 \%$ Triton X-100) $5 \mu \mathrm{L}, 2.5 \mathrm{U} / \mu \mathrm{L}$ DyNAzyme $^{\mathrm{TM}}$ polymerase $1 \mu \mathrm{L}$, 멸균 DW $38.5 \mu \mathrm{L}$ 에 추출 된 $\mathrm{gDNA} 2.5 \mu \mathrm{L}$ 를 넣어 총 $50 \mu \mathrm{L}$ 로 반응액을 만들었다. PCR은 TaKaRa PCR Thermal cycler (TP600 Gradient, Roche
Molecular System, CA, USA)를 사용하였고, 온도 조건을 $94^{\circ} \mathrm{C}$ 에서 5 분 predenaturation시킨 후, $94^{\circ} \mathrm{C}$ 에서 1 분 denaturation, $49^{\circ} \mathrm{C}$ 에서 1 분 annealing, $72^{\circ} \mathrm{C}$ 에서 1 분 extension을 1 주기로 36 회 실시하여 증폭하고 $72^{\circ} \mathrm{C}$ 에서 10 분간 postextension 을 실시하였다.

$\mathrm{PCR}$ 증폭산물은 $1.8 \%$ agarose gel을 사용하여 $100 \mathrm{~V}$ 로 30 분간 loading시켜 UV 투과조명기에서 확인하였고, GeneAll PCR DNA Purification kit (Geneall Biotechnology Co. LTD Seoul, Korea)를 사용하여 PCR 산물을 정제하였다. 그 후 Big dye PCR을 시행하였으며 Big dye PCR의 경우 Seq primer를 이용하였다. Forward와 reverse primer를 이용해 각 각 시행하였고, 반응액은 $5 \mathrm{pmol} \mathrm{seq} \mathrm{primer} 2 \mu \mathrm{L}$, 정제된 $\mathrm{PCR}$ 증폭산물 $3 \mu \mathrm{L}$, Big-dye $0.5 \mu \mathrm{L}, \mathrm{PCR}$ buffer $3 \mu \mathrm{L}$, 멸균 $\mathrm{DW} 4.5 \mu \mathrm{L}$ 를 혼합하여 총 $13 \mu \mathrm{L}$ 가 되도록 한 후 반응을 진행하였다. $96^{\circ} \mathrm{C}$ 에서 1 분간 predenaturation을 수행하고, $96^{\circ} \mathrm{C} 10$ 초, $50^{\circ} \mathrm{C} 5$ 초, $60{ }^{\circ} \mathrm{C} 4$ 분으로 구성된 순환조건을 25회 반응시킨 후 $3 \mathrm{M}$ sodium acetate를 이용한 침전과정과 $95 \% \mathrm{EtOH}$ 를 이용한 탈수과정을 거쳐 반응물질만을 정제 하였다. 정제된 반응물은 건조시켜 Hidi $10 \mu \mathrm{L}$ 에 녹인 후 ABI 3730XL DNA Analyzer (Applied Biosystems)를 이용해 염기서열을 분석하였다. 분석한 염기서열의 유사성 검색 은 NCBI data base인 BLAST를 이용하였다. 분석한 자료 중 $\mathrm{A} \geq 99.0 \%$ 의 유사성을 보이는 결과를 $\mathrm{CLSI}$ 의 기준을 적용하여 판독하였다(Chun et al., 2007; Wayne, 2007).

\section{결 과}

\section{분기별 혈액 배양에서 그람 양성 막대균(GPB)의 분리} 빈도

2014년 10월부터 2016년 9월까지 2년간 혈액 배양이 의 뢰된 총 87,241 건 중 $\mathrm{GPB}$ 의 분리 비율은 2014년 4분기 83 건(0.8\%), 2015년 1분기 68건(0.7\%), 2015년 2분기 83건 $(0.9 \%), 2015$ 년 3 분기 124 건(1.1\%), 2015년 4분기 84건

Table 1. Isolation rate of Gram positive bacilli in blood culture (2014-2016)

\begin{tabular}{|c|c|c|c|c|c|c|c|c|c|}
\hline $\begin{array}{l}\text { Quarter of } \\
\text { a year }\end{array}$ & $\begin{array}{c}4^{\text {th }} \text { quarter } \\
\text { of } 2014 \\
\mathrm{~N}(\%)\end{array}$ & $\begin{array}{c}1^{\text {st }} \text { quarter } \\
\text { of } 2015 \\
\mathrm{~N}(\%)\end{array}$ & $\begin{array}{c}2^{\text {nd }} \text { quarter } \\
\text { of } 2015 \\
\mathrm{~N}(\%)\end{array}$ & $\begin{array}{c}3^{\text {rd }} \text { quarter } \\
\text { of } 2015 \\
N(\%)\end{array}$ & $\begin{array}{c}4^{\text {th }} \text { quarter } \\
\text { of } 2015 \\
\mathrm{~N}(\%)\end{array}$ & $\begin{array}{c}1^{\text {st }} \text { quarter } \\
\text { of } 2016 \\
\mathrm{~N}(\%)\end{array}$ & $\begin{array}{c}2^{\text {nd }} \text { quarter } \\
\text { of } 2016 \\
\mathrm{~N}(\%)\end{array}$ & $\begin{array}{c}3^{\text {rd }} \text { quarter } \\
\text { of } 2016 \\
N(\%)\end{array}$ & Total \\
\hline $\begin{array}{l}\text { No. }(\%) \text { of } \\
\text { cases }\end{array}$ & $\begin{array}{c}83 / \\
10168 \\
(0.8 \%)\end{array}$ & $\begin{array}{c}68 / \\
9732 \\
(0.7 \%)\end{array}$ & $\begin{array}{c}83 / \\
9574 \\
(0.9 \%)\end{array}$ & $\begin{array}{c}124 / \\
11255 \\
(1.1 \%)\end{array}$ & $\begin{array}{c}84 / \\
11163 \\
(0.8 \%)\end{array}$ & $\begin{array}{c}65 / \\
11321 \\
(0.6 \%)\end{array}$ & $\begin{array}{c}105 / \\
11937 \\
(0.9 \%)\end{array}$ & $\begin{array}{c}101 / \\
12091 \\
(0.8 \%)\end{array}$ & $\begin{array}{c}713 / \\
87241 \\
(0.8 \%)\end{array}$ \\
\hline
\end{tabular}

$1^{\text {st }}$ quarter: Jan to Mar, $2^{\text {nd }}$ quarter: Apr to Jun, $3^{\text {rd }}$ quarter: Jul to Sep, $4^{\text {th }}$ quarter: Oct to Dec 
Table 2. Identification rate of Gram positive bacilli which showed 1.7 to 2.0 of MALDI-TOF MS cut-off scores (2014-2016)

\begin{tabular}{|c|c|c|c|c|c|c|c|}
\hline \multirow{2}{*}{$\begin{array}{l}\text { Species identification results by } \\
\text { MALDI-TOF MS system }\end{array}$} & \multicolumn{5}{|c|}{$\begin{array}{l}\text { No. of isolates with the number of } \\
\text { positive blood cultures per patient }\end{array}$} & \multirow{2}{*}{$\begin{array}{l}\text { Total No. }(\%) \\
\text { of patient }\end{array}$} & \multirow{2}{*}{$\begin{array}{l}\text { Total No. (\%) } \\
\text { of species }\end{array}$} \\
\hline & 1 & 2 & 3 & 4 & 5 & & \\
\hline Bacillus subtilis & 19 & 0 & 0 & 0 & 0 & $19(15.6)$ & $19(14.1)$ \\
\hline Bacillus cereus & 14 & 1 & 0 & 0 & 0 & $15(12.3)$ & $16(11.9)$ \\
\hline Corynebacterium striatum & 4 & 1 & 0 & 2 & 0 & $7(5.7)$ & $14(10.4)$ \\
\hline Corynebacterium afermentans & 10 & 0 & 0 & 0 & 0 & $10(8.2)$ & $10(7.4)$ \\
\hline Bacillus mojavensis & 8 & 0 & 0 & 0 & 0 & $8(6.6)$ & $8(5.9)$ \\
\hline Bacillus pumilus & 8 & 0 & 0 & 0 & 0 & $8(6.6)$ & $8(5.9)$ \\
\hline Bacillus sonorensis & 7 & 0 & 0 & 0 & 0 & $7(5.7)$ & $7(5.2)$ \\
\hline Bacillus licheniformis & 6 & 0 & 0 & 0 & 0 & $6(4.9)$ & $6(4.4)$ \\
\hline Bacillus vallismortis & 5 & 0 & 0 & 0 & 0 & $5(4.1)$ & $5(3.7)$ \\
\hline Mycobacterium abscessus & 0 & 0 & 0 & 1 & 0 & $1(0.8)$ & $4(3.0)$ \\
\hline Bacillus megaterium & 4 & 0 & 0 & 0 & 0 & $4(3.3)$ & $4(3.0)$ \\
\hline Microbacterium species & 3 & 0 & 0 & 0 & 0 & $3(2.5)$ & $3(2.2)$ \\
\hline Clostridium perfringens & 1 & 1 & 0 & 0 & 0 & $2(1.6)$ & $3(2.2)$ \\
\hline Eggerthella lenta & 2 & 0 & 0 & 0 & 0 & $2(1.6)$ & $2(1.5)$ \\
\hline Brevibacterium iodium & 0 & 1 & 0 & 0 & 0 & $1(0.8)$ & $2(1.5)$ \\
\hline Actinomyces odontolyticus & 2 & 0 & 0 & 0 & 0 & $2(1.6)$ & $2(1.5)$ \\
\hline Paenibacillus urinalis & 2 & 0 & 0 & 0 & 0 & $2(1.6)$ & $2(1.5)$ \\
\hline Solibacillus silvestis & 2 & 0 & 0 & 0 & 0 & $2(1.6)$ & $2(1.5)$ \\
\hline Bacillus circulans and others ${ }^{\mathrm{a}}$ & 18 & 0 & 0 & 0 & 0 & $18(14.8)$ & $18(13.3)$ \\
\hline Total & 115 & 4 & 0 & 3 & 0 & $122(100.0)$ & $135(100.0)$ \\
\hline
\end{tabular}

${ }^{\mathrm{a}}$ Bacillus muralis, Bacillus mycoisea, Bacillus niacini, Bacillus thuringiensis, Bacillus weienstephanensis, Clostridium bifermentans, Clostridium carnis, Clostridium innocuum, Corynebacterium singulare, Corynebacterium tuscaniense, Dermabacter hominis, Gordonarubropertincta, Lysinibacillus fusiformis, Microbacterium oxydans, Microbacterium testaceum, Paenibacillus latus, Paenibaillus xylanilyticus

(0.8\%), 2016년 1분기 65건(0.6\%), 2016년 2분기 105건(0.9\%), 2016년 3분기 101건(0.8\%)이었다. 연구기간 동안 혈액 배 양이 의뢰된 전체 건수 중 혈액 배양 양성률은 $10.0 \%$ 였 으며, GPB 양성률은 $0.8 \%$ 였다(Table 1$)$.

\section{MALDI-TOF MS System을 이용한 혈액 배양으로부터 분리된 그람 양성 막대균(GPB)의 동정}

\subsection{0의 cut-off score를 나타낸 GPB의 분리 비율:}

Cut-off score 1.7 20을 나타낸 GPB 중 Bacillus subtilis로 동정된 비율은 19건(14.1\%), Bacillus cereus는 15건(11.9\%), Corynebacterium striatum 는 14건(10.4\%), Corynebacterium afermentans 는 10건(7.4\%), Bacillus mojavensis 는 8건(5.9\%) 이었다(Table 2).
2.0 이상의 cut-off score를 나타낸 그람 양성 막대균 (GPB)의 분리 비율: Cut-off score를 1.7 이상 나타내며, $\mathrm{GPB}$ 로 동정된 총 410 건 중 275 건(67.1\%)은 2.0 이상의 높 은 cut-off score로 $\mathrm{GPB}$ 의 종 동정이 가능하였다. Cut-off score 2.0 이상을 나타낸 GPB 중 C. striatum 은 66건(27.3\%), B. cereus는 44건(16.0\%), Paenibacillus urinalis 은 27건(9.8\%), Listeria monocytogenes 는 25건(9.1\%), Clostridium perfringens 는 15 건(5.5\%)이었다(Table 3).

MALDI-TOF MS 분석 cut-off score에 따른 그람 양성 막대균(GPB)의 분리 비율: C. striatum과 B. cereus는 각각 2 년 동안 분리된 총 89 건 중 66 건(74.2\%), 60건 중 44건 (73.3\%)이 cut-off score 2.0 이상의 높은 수치로 동정 가능 하였고, L. monocytogenes와 C. perfingens는 각각 25건 중 25 건(100\%), 18 건 중 15 건(83.3\%)이 cut-off score 2.0 이상의 
Table 3. Identification rate of Gram positive which showed above 2.0 of MALDI-TOF MS cut-off scores (2014-2016)

\begin{tabular}{|c|c|c|c|c|c|c|c|c|c|c|}
\hline \multirow{2}{*}{$\begin{array}{l}\text { Species identification results by } \\
\text { MALDI-TOF MS system }\end{array}$} & \multicolumn{8}{|c|}{$\begin{array}{l}\text { No. of isolates with the number of } \\
\text { positive blood cultures per patient }\end{array}$} & \multirow{2}{*}{$\begin{array}{l}\text { Total No. }(\%) \\
\text { of patient }\end{array}$} & \multirow{2}{*}{$\begin{array}{l}\text { Total No. }(\%) \\
\text { of species }\end{array}$} \\
\hline & 1 & 2 & 3 & 4 & 5 & 6 & 7 & 8 & & \\
\hline Corynebacterium striatum & 17 & 9 & 1 & 3 & 2 & 0 & 1 & 1 & $34(16.7)$ & $75(27.3)$ \\
\hline Bacillus cereus & 35 & 3 & 1 & 0 & 0 & 0 & 0 & 0 & $39(19.1)$ & $44(16.0)$ \\
\hline Paenibacillus urinalis & 25 & 1 & 0 & 0 & 0 & 0 & 0 & 0 & $26(12.7)$ & $27(9.8)$ \\
\hline Listeria monocytogenes & 3 & 7 & 0 & 2 & 0 & 0 & 0 & 0 & $12(5.9)$ & $25(9.1)$ \\
\hline Clostridium perfringens & 9 & 3 & 0 & 0 & 0 & 0 & 0 & 0 & $12(5.9)$ & $15(5.5)$ \\
\hline Bacillus subtilis & 11 & 0 & 0 & 0 & 0 & 0 & 0 & 0 & $11(5.4)$ & $11(4.0)$ \\
\hline Bacillus licheniformis & 10 & 0 & 0 & 0 & 0 & 0 & 0 & 0 & $10(4.9)$ & $10(3.6)$ \\
\hline Clostridium tertium & 6 & 0 & 0 & 0 & 0 & 0 & 0 & 0 & $6(2.9)$ & $6(2.2)$ \\
\hline Microbacterium species & 1 & 0 & 0 & 1 & 0 & 0 & 0 & 0 & $2(1.0)$ & $5(1.8)$ \\
\hline Actinomyces oris & 4 & 0 & 0 & 0 & 0 & 0 & 0 & 0 & $4(2.0)$ & $5(1.8)$ \\
\hline Bacillus infantis & 4 & 0 & 0 & 0 & 0 & 0 & 0 & 0 & $4(2.0)$ & $4(1.5)$ \\
\hline Bacillus pumilus & 4 & 0 & 0 & 0 & 0 & 0 & 0 & 0 & $4(2.0)$ & $4(1.5)$ \\
\hline Bacillus megaterium & 3 & 0 & 0 & 0 & 0 & 0 & 0 & 0 & $3(1.5)$ & $3(1.1)$ \\
\hline Bacillus sonorensis & 3 & 0 & 0 & 0 & 0 & 0 & 0 & 0 & $3(1.5)$ & $3(1.1)$ \\
\hline Clostridium carnis & 0 & 0 & 1 & 0 & 0 & 0 & 0 & 0 & $1(0.5)$ & $3(1.1)$ \\
\hline Eggerthella lenta & 3 & 0 & 0 & 0 & 0 & 0 & 0 & 0 & $3(1.5)$ & $3(1.1)$ \\
\hline Bacillus mojavensis & 2 & 0 & 0 & 0 & 0 & 0 & 0 & 0 & $2(1.0)$ & $2(0.7)$ \\
\hline Bacillus mycoisea & 2 & 0 & 0 & 0 & 0 & 0 & 0 & 0 & $2(1.0)$ & $2(0.7)$ \\
\hline Corynebacterium minutissimun & 2 & 0 & 0 & 0 & 0 & 0 & 0 & 0 & $2(1.0)$ & $2(0.7)$ \\
\hline Corynebacterium urealyticum & 0 & 1 & 0 & 0 & 0 & 0 & 0 & 0 & $1(0.5)$ & $2(0.7)$ \\
\hline Lactobacillus paracasei & 2 & 0 & 0 & 0 & 0 & 0 & 0 & 0 & $2(1.0)$ & $2(0.7)$ \\
\hline Microbacterium aurum & 2 & 0 & 0 & 0 & 0 & 0 & 0 & 0 & $2(1.0)$ & $2(0.7)$ \\
\hline Mycobacterium abscessus & 0 & 1 & 0 & 0 & 0 & 0 & 0 & 0 & $1(0.5)$ & $2(0.7)$ \\
\hline Paenibacillus illinoisensis & 2 & 0 & 0 & 0 & 0 & 0 & 0 & 0 & $2(1.0)$ & $2(0.7)$ \\
\hline $\begin{array}{l}\text { Actinomyces odontolyticus } \\
\text { and others }{ }^{\mathrm{a}}\end{array}$ & 16 & 0 & 0 & 0 & 0 & 0 & 0 & 0 & $16(7.8)$ & $16(5.8)$ \\
\hline Total & 166 & 25 & 3 & 6 & 2 & 0 & 1 & 1 & $\begin{array}{c}204 \\
(100.0)\end{array}$ & $\begin{array}{c}275 \\
(100.0)\end{array}$ \\
\hline
\end{tabular}

${ }^{\mathrm{a}}$ Arthrobacteroxydans, Bacillus atrophaeus, Bacillus flexus, Bacillus thermoamylovorans, Bacillus thuringiensis, Corynebacterium amycolatum, Corynebacterium falsenii, Corynebacterium pseudodiphthriticum, Exigubacterium aurantiacum, Lactobaillus salivarius, Lysinibacillus fusiformis, Paenibacillus barengoltzii, Paenibacillus rhizosphaerae, Paenibacillus odorifer, Paenibacillus pauli

높은 수치로 동정 가능하였다(Table 4).

\section{혈액 배양으로부터 분리된 그람 양성 막대균(GPB) 동정 을 위한 16S rDNA 염기서열 분석과 MALDI-TOF MS system의 결과 비교}

세균의 $16 \mathrm{~S} \mathrm{rDNA}$ 염기서열 분석과 MALDI-TOF MS 분석을 동시에 실시한 총 50 건 중 43 건(86.0\%)은 두 분석 에서 결과가 일치하였으며, 7 건(14.0\%)은 결과가 일치하
지 않았다. 두 분석에서 일치한 결과를 나타낸 경우는 $C$. striatum 19건, L. monocytogenes 9건, C. perfringens 5 건, $B$. iodinum 1건, Clostridium canis 1건, Corynebacterium urealyticum 1건, Mycobacterium abscessus 1건, P. urinalis 1건 이었 다. 두 분석에서 불일치를 나타낸 7건 중 MALDI-TOF MS 분석에서 cut-off score 1.7 이상을 나타냈던 경우는 총 2건 으로 B. cereus는 Lysinbacillus spp.로, Microbacterium spp.는 Mycobacterium paraoxydans로 각각 불일치한 결과를 나타 
Table 4. Distribution of Gram positive bacilli species from blood culture according to the cut-off scores of MALDI-TOF MS (2014-2016)

\begin{tabular}{lccc}
\hline \hline \multicolumn{1}{c}{$\begin{array}{c}\text { Species identification results by } \\
\text { MALDI-TOF MS system }\end{array}$} & Score & Score & Total No. of species \\
\hline Corynebacterium striatum & $\leq 2.0 \sim 1.7$ & $\geq 2.0$ & 89 \\
Bacillus cereus & 14 & 75 & 60 \\
Bacillus subtilis & 16 & 44 & 30 \\
Paenibacillus urinalis & 19 & 11 & 29 \\
Listeria monocytogenes & 2 & 27 & 25 \\
Clostridium perfringens & 0 & 25 & 18 \\
Bacillus licheniformis & 3 & 15 & 16 \\
Bacillus pumilus & 6 & 10 & 12 \\
Other species & 8 & 4 & 131 \\
Not reliable identification & 67 & 64 & 213 \\
No peaks found & - & - & 90 \\
\hline \multicolumn{1}{c}{ Total } & - & - & 713 \\
\hline
\end{tabular}

Table 5. Comparison of the results of MALDI-TOF MS and 16S rDNA sequence analysis with double positive cases in blood culture of the same patient

\begin{tabular}{|c|c|c|c|c|c|c|}
\hline \multirow{2}{*}{$\begin{array}{l}\text { Species identification results by } \\
\text { MALDI-TOF MS System }\end{array}$} & \multicolumn{5}{|c|}{ No. of isolates } & \multirow{2}{*}{$\begin{array}{c}\text { Fianl ID result by } \\
\text { 16S-rRNA } \\
\text { sequencing }\end{array}$} \\
\hline & $\begin{array}{l}2.0 \leq \\
\text { Score }\end{array}$ & $\begin{aligned} 1.7 & \leq \text { Score } \\
& \leq 2.0\end{aligned}$ & $\begin{array}{c}\text { Score }< \\
1.7\end{array}$ & $\begin{array}{l}\text { Concordant } \\
\text { result }\end{array}$ & $\begin{array}{l}\text { Discordant } \\
\text { result }\end{array}$ & \\
\hline Corynebacterium striatum & 17 & 2 & & 19 & 0 & \\
\hline Bacillus cereus & 5 & 1 & & 5 & 1 & Lysinbacillus sp. \\
\hline Clostridium perfringens & 4 & 1 & & 5 & 0 & \\
\hline Listeria monocytogenes & 9 & & & 9 & 0 & \\
\hline Bacillus iodinum & & 1 & & 1 & 0 & \\
\hline Clostridium carnis & 1 & & & 1 & 0 & \\
\hline Corynebacterium urealyticum & 1 & & & 1 & 0 & \\
\hline Microbacterium species & 1 & & & 0 & 1 & $\begin{array}{l}\text { Mycobacterium } \\
\text { paraoxydans }\end{array}$ \\
\hline Mycobacterium abscessus & & 1 & & 1 & 0 & \\
\hline Paenibacillus urinalis & 1 & & & 1 & 0 & \\
\hline \multirow[t]{4}{*}{ Not reliable identification } & & & 4 & 0 & 4 & Cellulomonas hominis \\
\hline & & & & & & $\begin{array}{l}\text { Corynebacterium } \\
\text { amycolatum }\end{array}$ \\
\hline & & & & & & $\begin{array}{l}\text { Catabacter } \\
\text { hongkongenesis }\end{array}$ \\
\hline & & & & & & Bacillus sp. \\
\hline No peaks found & & & & 0 & 1 & Bacillus velezensis \\
\hline Total & 39 & 6 & 4 & 43 & 7 & \\
\hline
\end{tabular}

냈다. 두 분석에서 불일치한 결과를 나타낸 나머지 5주는 MALDI-TOF MS 분석에서 not reliable identification 혹은 no peaks found의 결과를 나타냈고, $16 \mathrm{~S} \mathrm{rDNA}$ 분석을 실

시한 결과 각각은 Cellulomonas hominis, Corynebacterium 
amycdatum, Catabacter hongkongenesis, Bacillus spp., Bacillus velezensis로 동정되었다(Table 5).

\section{고 찰}

기존의 연구들을 통해 임상적으로 의의가 있는 GPC, $\mathrm{GNB}$, 진균의 대부분은 MALDI-TOF MS 분석으로 종과 속의 수준까지 간편하고 신속하게 동정이 가능함이 현재 까지 확인되었다(Bernard et al., 2012; Levesque et al., 2015). 하지만, 상대적으로 오염균으로 여겨지던 $\mathrm{GPB}$ 에 대한 기 존의 연구와 임상적 유용성 평가 결과는 결여되어 있어 본 연구를 통해 혈액 배양에서 분리되는 $\mathrm{GPB}$ 의 동정이 MALDI-TOF MS 분석을 통해 유용성이 있는지 분석해 보 았다. 따라서, 국내의 한 대학병원에서 2 년간 시행된 총 87,241 건의 혈액 배양 중 $\mathrm{GPB}$ 가 분리된 713 건 $(0.8 \%)$ 을 대상으로 연구를 실시하였다.

장비 회사에서 제공하는 기준에 따라 균과 속의 동정이 가능한 cut-off score 1.7 이상을 나타낸 경우는 총 410건 $(57.5 \%)$ 이었다. 동정은 가능하였으나, cut-off score가 1.7 이하로 신뢰할 수 없는 결과를 보였던 경우는 총 213건 (29.9\%) 이었으며, 분석 결과가 No peaks found로 동정조차 힘들었던 경우는 90건(12.6\%)에 달했다. Cut-off score 1.7 이상을 나타낸 경우 C. striatum으로 동정된 경우는 89건 (12.4\%), B. cereus는 60건(8.4\%), B. subtilis 30건(4.2\%), P. urinalis 는 29건(4.1\%), L. monocytogenes는 25건(3.5\%)이었 다. Corynebacterium spp., Bacillus spp., Listeria spp.은 임상 적으로도 의의가 많은 감염균으로서 높은 비율을 보임을 알 수 있었다(Renom et al., 2012; Severo et al., 2014). 또한 분리 비율은 적지만 Mycobacterium spp. 과 Clostridium spp. 은 cut-off score 1.7 이상의 신뢰할 수 있는 결과로 동정이 가능함을 알 수 있었다. 물론 not reliable identification 혹은 no peaks found의 결과를 나타낸 경우도 $42.5 \%$ 로 높은 비 율을 차지하였으나, 거의 대부분의 경우 1 회 분리균은 오 염균으로 간주되기 때문에 감염균으로의 의의가 없는 것 으로 사료된다.

Cut-off score 2.0 이상으로 동정된 균 종과 cut-off score 1.7 2.0으로 동정된 균 종을 비교해 보면 cut-off score 1.7 이상으로 동정된 총 410 건 중 275 건(67.1\%)은 2.0 이상의 높은 cut-off score로 동정이 가능했다. Cut-off score 2.0 이 상인 경우는 C. striatum이 66건(27.3\%), B. cereus가 44건 (16.0\%), P. urinalis 가 27건(9.8\%), L. monocytogenes가 25건 (9.1\%), C. perfringens 가 15건(5.5\%)이었고, cut-off score 1.7
2.0로 동정된 균 종은 B. subtilis가 19건(14.1\%), B. cereus가 15 건(11.9\%), C. striatum 가 14건(10.4\%), C. afermentans가 10 건(7.4\%), B. mojavensis가 8건(5.9\%)이었다. C. striatum과 B. cereus는 각각 2 년 동안 분리된 총 89 건 중 66 건(74.2\%), 60건 중 44건(73.3\%)을 cut-off score 2.0 이상의 높은 신뢰 도를 가지고 동정이 가능했다. 또한, 1 회만 분리되어도 의 의가 있는 L. monocytogenes는 25건 모두가 cut-off score 2.0 이상을 나타냈다.

$\mathrm{GPB}$ 이지만 동일 환자에서 2회 이상 분리된 경우 감염 원으로 간주되기 때문에 이러한 조건에 해당하는 총 50 건 은 $16 \mathrm{~S} \mathrm{rDNA}$ 염기서열 분석을 통해 재확인 절차를 진행 하였으며, 최종 결과를 비교해 보았다. 총 50 건 중 43 건 $(86.0 \%)$ 은 MALDI-TOF MS와 $16 \mathrm{~S} \mathrm{rDNA}$ 염기서열 분석 결 과가 일치하였고, 나머지 7건(14.0\%)은 불일치 하는 결과 를 나타냈다.

본 연구의 결과를 토대로 지난 2년간의 혈액 배양에서 분리된 $\mathrm{GPB}$ 의 절반 이상이 MALDI-TOF MS 분석 시 cutoff score 1.7 이상의 신뢰할 수 있을만한 수준으로 균 종 동정이 가능했고, 그 중 1 회만 분리되어도 임상적 의의가 있는 균 종, 동일 환자에서 2회 이상 분리되어 오염균이 아닌 감염균으로 간주되는 균 종은 세균 $16 \mathrm{~S} \mathrm{rDNA}$ 염기 서열 분석 결과와 $86.0 \%$ 의 높은 일치율을 나타냈다. 추가 적으로, 세균의 $16 \mathrm{~S} \mathrm{rDNA}$ 염기서열 분석과 MALDI-TOF $\mathrm{MS}$ 분석을 동시에 실시한 총 50 건 중 39 건(78.0\%)은 cutoff score 2.0 이상, 6건(12.0\%)은 cut-off score 1.7 이상의 높 은 신뢰도로 균 종 동정이 가능했으며, 총 2건(4.0\%)에서 만 MALDI-TOF MS와 세균의 $16 \mathrm{~S} \mathrm{rDNA}$ 염기서열 분석 결과가 일치하지 않았다. 이러한 결과들을 기반으로 하여, 기존에 오염균으로 생각되어 거의 동정되지 않았던 $\mathrm{GPB}$ 균 종을 MALDI-TOF MS System을 이용해 1차 동정을 실 시하고, 임상적 의의가 있는 균 종에 대해서는 $16 \mathrm{~S} \mathrm{rDNA}$ 염기서열 분석을 추가적으로 적용하여 결과를 활용한다면, 향후 감염원으로서 의의가 있는 GPB 동정에 매우 유용할 것으로 사료된다.

하지만, 환자로부터 흔히 분리되지 않고, 비병원성 세 균이 많이 포함되어 있는 $\mathrm{GPB}$ 의 특성으로 인해 현재 MALDI-TOF MS를 이용해 균 종 동정을 하기 위한 데이 터베이스가 부족하고, 협막이 존재하는 일부 $\mathrm{GPB}$ 의 구조 적 특성상 단백질 분리의 어려움이 있기 때문에 동정이 힘든 경우가 많이 확인되었다. 추후 MALDI-TOF MS를 이용해 GPB 균 종을 동정할 수 있는 데이터베이스를 더 욱 확충하고, 협막 보유 세균을 위해 추가 보완된 단백질 
분리 방법이 사용된다면, $\mathrm{GPB}$ 의 신속 정확한 동정에 많은 도움이 될 수 있을 것으로 사료된다.

\section{ACKNOWLEDGEMENTS}

None.

\section{CONFLICT OF INTEREST}

The authors have no conflicts of interest to disclose.

\section{REFERENCES}

Adderso EE, Boudreaux JW, Hayden RT. Infections caused by coryneform bacteria in pediatric oncology patients. Pediatr Infect Dis J. 2008. 27: 136-141.

Barberi C, Almuzara M, Join-Lambert O, Ramirez MS, Famiglietti A. Comparison of the Bruker MALDI-TOF Mass Spectrometry System and Conventional Phenotypic Methods for Identification of Gram-Positive Rods. PLoS ONE. 2014. 9: e106303.

Bernard $\mathrm{K}$. The genus corynebacterium and other medically relevant coryneform-like bacteria. J Clin Mircobiol. 2012. 50: 3152 $-3158$

Bizzini A, Durussel C, Bille J, Greub G, Prod'hom G. Performance of matrix-assisted laser desorption ionization-time of flight mass spectrometry for identification of bacterial strains routinely isolated in a clinical microbiology laboratory. J Clin Microbiol. 2010. 48: 1549-1554.

Carbonnelle E, Grohs P, Jacquier H, Day N, Tenza S, Dewailly A, Vissouarn O, Rottman M, Herrmann JL, Podglajen I, Raskine L. Robustness of two MALDI-TOF mass spectrometry systems for bacterial identification. J Microbiol Methods. 2012. 89: 133-136.

Chun J, Lee JH, Jung Y, Kim M, Kim S, Kim BK, et al. EzTaxon: a web-based tool for the identification of prokaryotes based on 16S ribosomal RNA gene sequences. Int J Syst Evol Microbiol. 2007. 57: 2259-2261.

Dubois D, Grare M, Prere MF, Segonds C, Marty N, Oswald E. Performances of the Vitek MS matrix-assisted laser desorption ionization-time of flight mass spectrometry system for rapid identification of bacteria in routine clinical microbiology. $\mathrm{J}$ Clin Microbiol. 2012. 50: 2568-2576.

Funke G, von Graevenitz A, Clarridge JE 3rd, Berneard KA. Clinical microbiology of coryneform bacteria. Clin Microbiol Rev. 1997. 10: $125-129$.

Holland RD, Wilkes JG, Rafii F, Sutherland JB, Persons CC, Voorhees KJ, et al. Rapid identification of intact whole bacteria based on spectral patterns using matrix-assisted laser desorption/ionization with time-of-flight mass spectrometry. Rapid Commun Mass Spectrom. 1996. 10: 1227-1237.

Levesque S, Dufresne PJ, Soualhine H, Doming M-C, Bekal S, Lefebvre B, et al. A side by side compariton of Bruker Biotyper and VITEK MS: Utility of MALDI-TOF MS Technolo gy for Microorganism Identification in a Public Health Reference Laboratory. PLoS ONE. 2015. 10: e0144878.

Renom F, Gomila M, Garau M, Gallegos MDC, Guerrero D, Lalucat J, Soriano JB. Respira tory infection by Corynebacterium striatum: epidemiological and clinical determinants. New Micorbes New Infect. 2014. 2: 106-114.

Seng P, Drancourt M, Gouriet F, La Scola B, Fournier PE, Rolain $\mathrm{JM}$, et al. Ongoing evolution in bacteriologyl routine identification of bacteria by matrix-assisted laser desorption ionization itme-offlight mass spectrometry. Clin Infect Dis. 2009. 49: 543 -551 .

Severo CB, Guazzelli LS, Barra MB, Hochhegger B, Severo LC. Multiple pulmonary nodules caused by Corynebacterium striatum in an immunocompetent patient. Rev Inst Med Trop Sao Paulo. 2014. 56: 89-91.

Stevenson LG, Drake SK, Shea YR, Zelazny AM, Murray PR Evaluation of matrix-assisted laser desorption ionization-time of Flight mass spectrometry for identification of clinically important yeast species. J Clin Microbiol. 2010. 48: 3482-3486.

Wayne PA. Clinical and Laboratory Standards Institute. Interpretive criteria for identify cation of bacteria and fungi by DNA target sequencing; approved guideline MM-18A. Clinical and Laboratory Standards Institute. 2007.

https://doi.org/10.15616/BSL.2018.24.2.108

Cite this article as: Choi JU, Kim SH, Hwang SJ, Yu YB, Kim S, Kim YK. Availability of MADLDI-TOF MS for Identification of Gram Positive Bacilli Isolated from Blood Culture. Biomedical Science Letters. 2018. 24: $108-115$ 